\title{
ANALISIS PEMBELAJARAN DENGAN MENGGUNAKAN SOFTWARE GEOGEBRA DALAM PEMBELAJARAN MATEMATIKA
}

\author{
Yakin Niat Telaumbanua \\ FPMIPA, IKIP Gunungsitoli \\ e-mail: telaumbanua.yakin@yahoo.com
}

\begin{abstract}
Researchers conduct research on the use of Geogebra Software in Mathematics Learning ". This study aims to analyze the learning process by using geogebra software in mathematics learning. This research method is to use a qualitative description approach. Based on the research conducted, several research results are obtained, namely: 1) Geogebra software can be easily owned by students, 2) Geogebra software is easy to learn by students, 3) Learning by using geogebra software is fun and interesting, 4) students become motivated to learn , 5) mathematical problems can be easily and quickly resolved, and can draw graphs faster, interesting and varied
\end{abstract}

Keyword: Mathematics Learning Process, Geogebra Software

\begin{abstract}
Abstrak.Peneliti melakukan penelitian tentang penggunaan Software Geogebra dalam Pembelajaran Matematika". Penelitian ini bertujuan untuk menganalisis proses pembelajaran dengan penggunaan software geogebra dalam pembelajaran matematika. Metode Penelitian ini adalah dengan menggunakan pendekatan kualitatif deskripsi. Berdasarkan penelitian yang dilakukan maka diperoleh beberapa hasil penelitian, yaitu: 1) Software geogebra dapat dengan mudah dimiliki oleh mahasiswa, 2) Software geogebra mudah dipelajari oleh mahasiswa, 3) Pembelajaran dengan menggunakan, software geogebra menyenangkan dan menarik, 4) mahasiswa menjadi termotivasi untuk belajar, 5) soal matematika dapat dengan mudah dan cepat diselesaikan, serta dapat menggambar grafik dengan lebih cepat, menarik dan bervariasi.
\end{abstract}

Kata Kunci: Proses Pembelajaran Matematika, Software Geogebra 


\section{PENDAHULUAN}

Dalam pembelajaran matematika, siswa kadang mengalami kesulitan dalam memahami materi yang disampaikan oleh guru. Siswa juga kadang lamban dalam mengolah informasi yang disampaikan oleh guru sehingga informasi yang disampaikan oleh guru terlewat begitu saja tanpa dipahami oleh siswa.

Hal tersebut terjadi karena penyampaian informasi yang dilakukan oleh guru kurang melibatkan keatifan dan visual siswa Pembelajaran yang melibatkan keatifan dan visual siswa dapat membuat informasi yang disampaikan bisa dengan mudah diterima, ditangkap dan dipahami oleh siswa dan informasi yang diterima dapat bertahan lama diingatan siswa.

Salah satu pembelajaran yang dapat melibatkan keaktifan dan visual siswa seiring dengan kemajuan ilmu pengetahuan di era globalisasi ini adalah dengan menggunakan teknologi komputer. Komputer dapat dengan mudah mengkomunikasikan dan mentransfer ilmu pengetahuan.

Komputer memiliki salah satu
software atau aplikasi yang dapat
mengkomunikasikan dan mentransfer ilmu
pengetahuan. Software tersebut adalah
software geogebra. Menurut Ekawati (2016),
geogebra merupakan aplikasi yang digunakan
untuk geometri, aljabar, dan kalkulus secara
geometri.

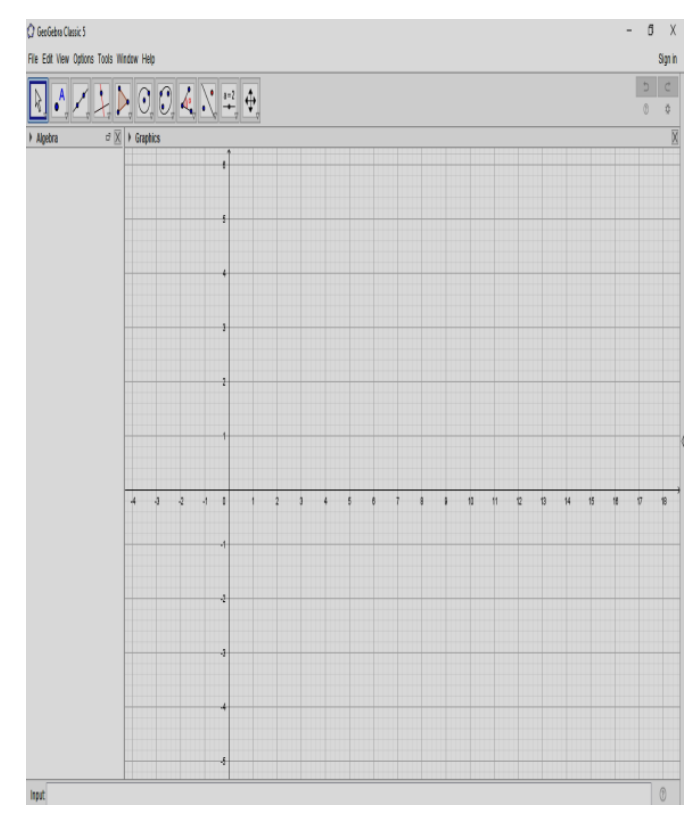

Gambar 1 Tampilan Lembar Kerja Software
Geogebra

Hohenwarter \& Fuchs (Nopiyani, Turmudi dan Prabawanto, 2016) mengatakan bahwa geogebra sangat bermanfaat sebagai: 1) media demontrasi dan visualisasi; 2) alat bantu konstruksi; 3) alat bantu proses penemuan; dan 4) alat komunikasi dan representasi. Software geogebra adalah salah satu aplikasi komputer yang bisa digunakan dalam pembelajaran matematika, karena kemampuannya dalam menggambarkan sebuah titik, garis, grafik, bangun serta menentukan penyelesaian dari sebuah persamaan linear, persamaan kuadrat, persamaan lingkaran dan sebagainya.

Menurut Ekawati (2016) geogebra dapat digunakan sebagai media pembelajaran, bahan ajar dan alat bantu menyelesaiakn soal matematika. Selanjutnya dikatakannya bahwa dengan geogebra dapat membantu siswa dalam mengkontruksi masalah matematika sendiri dan memecahkan masalah tersebut dengan geogebra.Sehingga geogebra 
membuat matematika lebih interaktif dan menarik.

Berdasarkan uraian tersebut di atas, maka peneliti melakukan penelitian tentang penggunaan software geogebra dalam Pembelajaran Matematika".

\section{METODE}

Penelitian ini akan dilaksanakan kepada Mahasiswa Program Studi Pendidikan Matematika Fakultas FPMIPA IKIP Gunungsitoli semester II. Metode Penelitian ini adalah dengan menggunakan pendekatan kualitatif deskripsi.

Data yang diperoleh dari hasil penelitian di analisis untuk diketahui hasilnya sehingga dapat ditarik kesimpulan tentang penelitian yang dilakukan.

1. Observasi

Hasil observasi dianalisis dengan melihat bagaimana keaktifan mahasiswa selama proses pembelajaran dan bagaimana kemampuan mahasiswa saat menggunakan software geogebra.

2. Wawancara

Data hasil wawancara dianalisis berdasarkan jawaban-jawaban dari mahasiswa. Dari jawaban-jawaban siswa bisa diperoleh informasi tentang apa yang dirasakan mahasiswa serta bagaimana proses pembelajaran dengan menggunakan software geogebra.

\section{HASIL DAN PEMBAHASAN}

Berdasarkan penelitian yang dilakukan kepada Mahasiswa Matematika Fakultas
FPMIPA IKIP Gunungsitoli, maka diuraikan hasil dan pembahasan penelitian tentang penggunaan software geogebra dalam pembelajaran matematika yang diuraikan di bawah ini.

\section{Hasil}

Hasil penelitian diperoleh dari hasil observasi penelitian, hasil wawancara dan hasil kerja mahasiswa.

\section{Hasil Observasi Penelitian}

Berdasarkan observasi penelitian yang dilakukan selama proses pembelajaran matematika maka diperoleh beberapa hasil penelitian, yaitu:

a. Software geogebra dapat dengan mudah dimiliki oleh mahasiswa

Mahasiswa dalam pembelajaran matematika telah mendapatkan Software geogebra dengan mudah dengan mendownload aplikasinya di situs www.geogebra.org. dan kemudian menginstalnya di komputer atau laptop masing-masing.

b. Software geogebra mudah dipelajari oleh mahasiswa

Berdasarkan hasil observasi yang dilakukan ketika proses pembelajaran matematika berlangsung, mahasiswa dengan mudah menggunakan Software geogebra setelah mendengarkan penjelasan dari pengajar tentang 
tata cara penggunaannya. Selain

itu, mahasiswa juga dengan mudah belajar dan mendapatkan pengetahuan yang lebih dalam menggunakan aplikasi ini setelah membaca berbagai literatur dari berbagai pencarian di internet. Sehingga banyak hal yang sangat bervariasi yang telah mereka dapatkan dari pencarian yang mereka lakukan di internet.

c. Mahasiswa menjadi termotivasi untuk belajar

Mahasiswa dalam

menggunakan aplikasi ini memiliki semangat atau motivasi yang tinggi dan aktif dalam belajar. Mahasiswa memiliki inisiatif sendiri untuk bertanya, mencari informasi dan berusaha untuk bisa menyelesaiakan tugastugas yang diberikan terkait penggunaan software geogebra, sehingga dari hal tersebut tampak keaktifan siswa dalam proses pembelajaran.

\section{Hasil Wawancara}

Berdasarkan wawancara yang dilakukan peneliti kepada mahasiswa, berikut disampaikan hasil wawancara berupa pertanyaan dari peneliti dan jawaban dari narasumber (mahasiswa):

a) Pewawancara : Bagaimana pembelajaran dengan menggunakan software geogebra?
Naraumber:Pembelajaran dengan menggunakan software geogebra menyenangkan dan menarik.

b) Pewawancara:Apakah anda sudah bisa menggunakan software geogebra?

Naraumber : Bisa Pak

c) Pewawancara:Apakah anda mudah menggunakan software geogebra?

Naraumber: Mudah Pak, terlebih ada banyak informasi yang bisa didapat tentang petunjuk penggunaan aplikasinya dari internet.

d) Pewawancara :Apa yang anda rasakan setelah belajar dengan menggunakan software geogebra? Naraumber : Soal dapat dengan mudah dan cepat diselesaikan, serta kita dapat menggambar grafik dengan lebih cepat, menarik dan bervariasi.

Berdasarkan wawancara tersebut, maka hasil analisa dari wawancara yaitu:

a. Software geogebra dapat digunakan dengan baik

b. Software geogebra mudah digunakan terlebih ada banyak informasi yang bisa didapat tentang petunjuk penggunaan aplikasinya dari internet.

c. Dapat menggambar grafik dengan lebih cepat, menarik dan bervariasi. 


\section{Hasil Kerja Siswa}

Berikut disampaikan hasil kerja mahasiswa tentang pengaplikasian penggunaan software geogebra

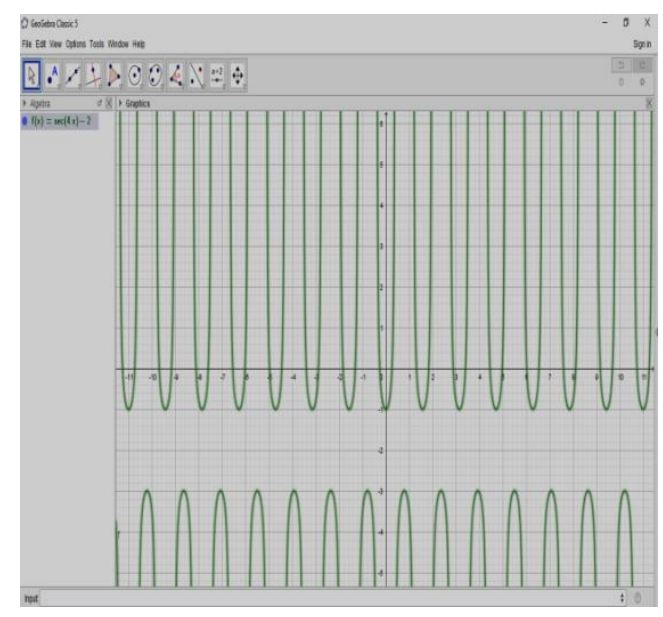

Gambar 2. Hasil Kerja 1 Software Geogebra

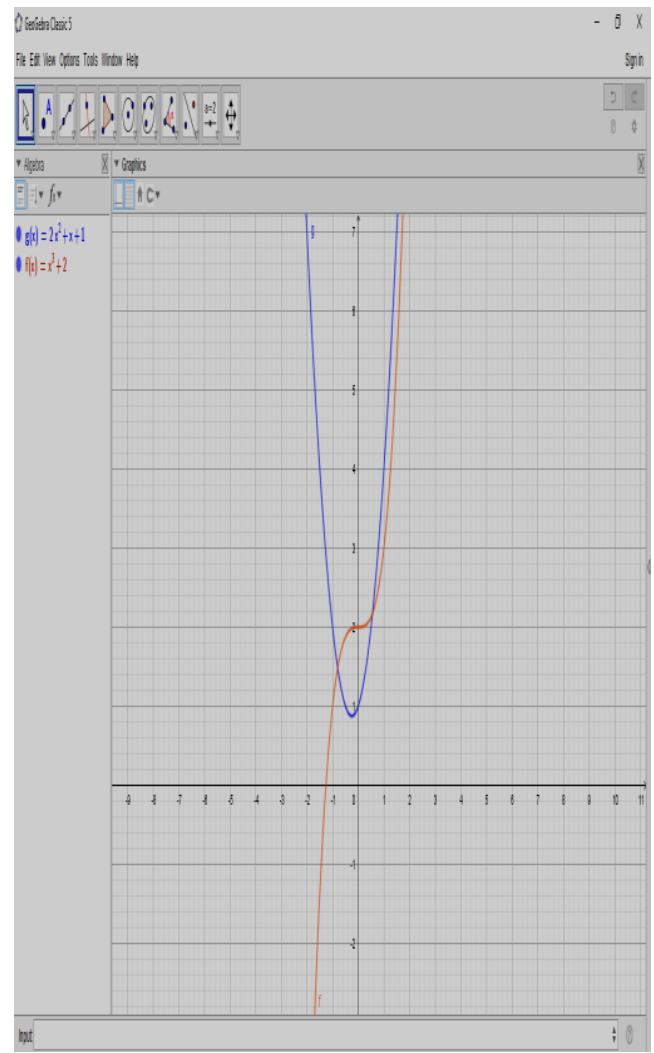

Gambar 3. Hasil Kerja 2 Software Geogebra

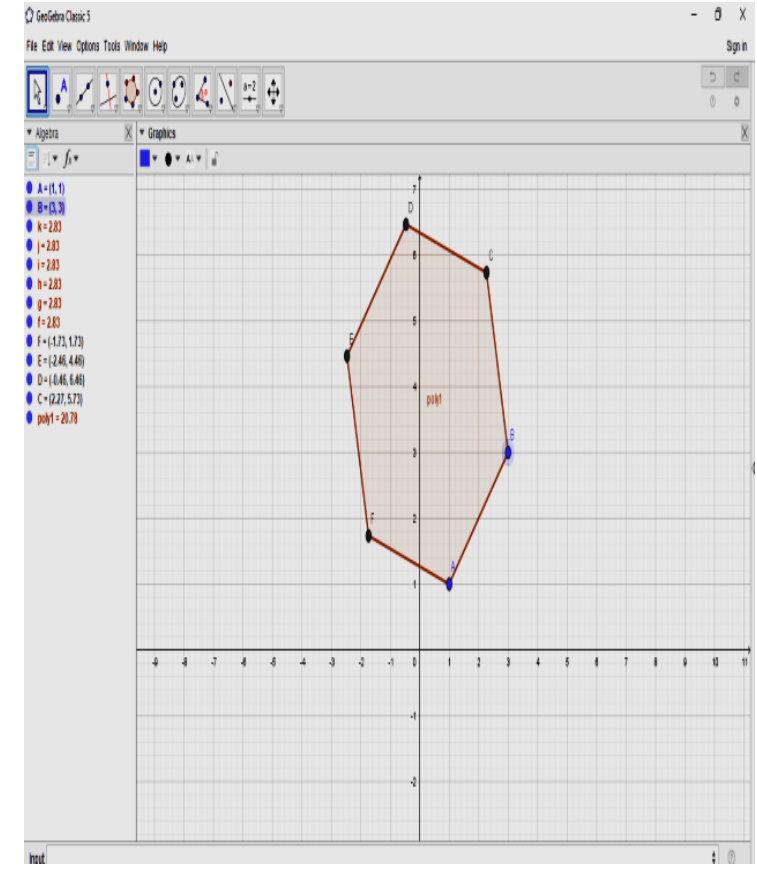

Gambar 4. Hasil Kerja 3 Software Geogebra

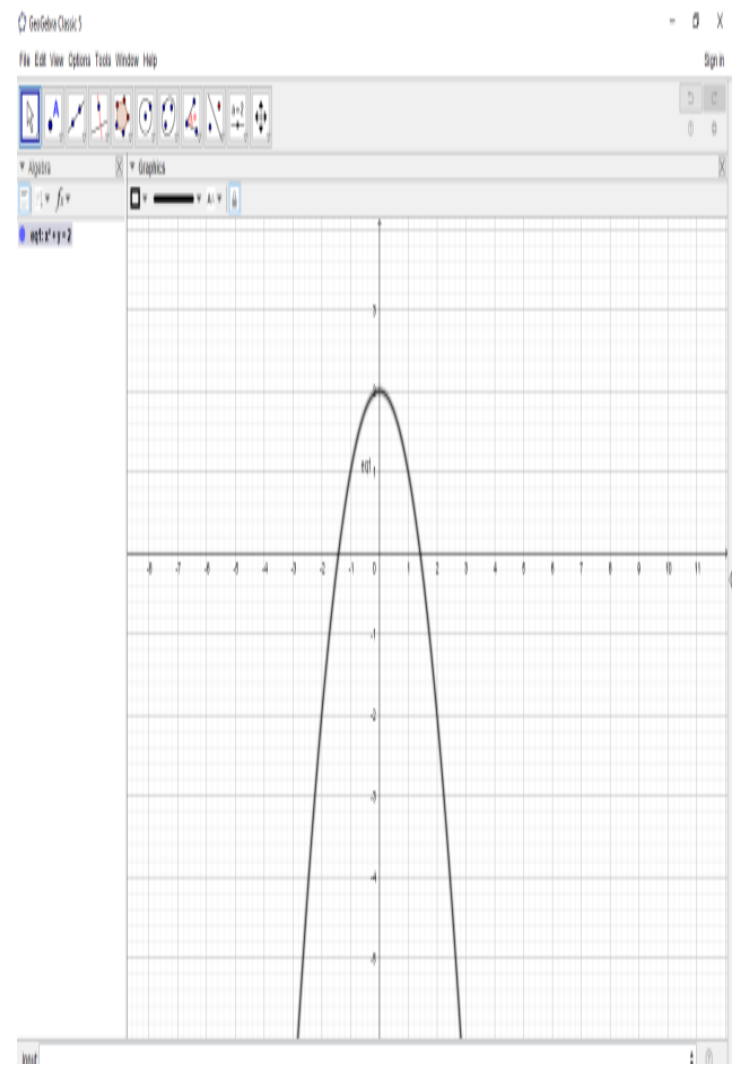

Gambar 5. Hasil Kerja 4 Software Geogebra 


\section{Pembahasan}

Salah satu hal yang dapat membuat peserta didik termotivasi dalam proses pembelajaran adalah proses pembelajaran yang menyenangkan dan menarik. Pembelajaran yang menarik perhatian peserta didik dapat didesain dengan bantuan teknologi. Dari penelitian ini, Nampak bahwa pembelajaran menjadi lebih menarik dan lebih mudah bagi mahasiswa karna bantuan software geogebra.Penelitian ini sejalan dengan pendapat Ardina (2016) bahwa, teknologi dapat membuat siswa lebih tertarik untuk mempelajari materi yang sedang dipelajari dan merasa senang dalam mengikuti proses pembelajaran. Dikatakannya bahwa penggunaan teknologi dalam matematika ini dapat berupa media audio, visual ataupun audiovisual. Dalam penelitian ini, salah satu media audiovisual yang digunakan sebagai alat bantu belajar mahasiswa adalah geogebra. Geogebra merupakan salah satu media pembelajaran matematika yang berbasis sistem komputasi geometri dinamis.

Dalam proses pembelajaran matematika yang dilakukan, mahasiswa mendapatkan pengetahuan baru yaitu dengan mengetahui software geogebra dan dapat menggunakan aplikasi tersebut dalam menggambar garis, grafik dan persaamaan garis. Hal tersebut mendukung teori yang disampaikan oleh Sagala (2011:12) bahwa belajar adalah kegiatan individu memperoleh pengetahuan, perilaku dan keterampilan dengan cara mengolah bahan ajar. Demikian juga menurut Cronbach (Hosnan, 2013:3), "learning is shown by a change in behavior as a result of experience". Maksudnya belajar adalah perubahan perilaku sebagai hasil dari pengalaman. Demikain juga menurut Suparman (2014:9) bahwa pembelajaran adalah suatu rangkaian peristiwa yangmempengaruhi siswa sedemikian rupa sehingga perubahan hasil belajar terfasilitasi.

Uno (2011:129) mengatakan, "bahwa matematika adalah sebagai suatu bidang ilmu yang merupakan alat berpikir, berkomunikasi, alat untuk memecahkan berbagai persoalan praktis, yang unsur-unsurnya logika dan intuisi, analisis dan konstruksi, generalitas dan individualitas...". Hal yang disampaikan oleh Uno tersebut dibantu oleh penggunaan software geogebra dalam belajar matematika.

Hendriana, Benny (2017) mengatakan bahwa geogebra adalah software matematika dinamis yang dapat digunakan sebagai alat bantu dalam pembelajaran matematika dan dimulai dirintis oleh Markus Hohenwarter pada tahun 2001 sebagai bagian dari thesis masternya pada saat menyelesaikan program pendidikan matematika dan ilmu komputer di Universitas Salzburg, Austria.

Menurut Zayyadi, Lanya, \& Irawati (2019:58) geogebra dapat digunakan sebagai media pembelajaran matematika untuk belajar (visualisasi, komputasi, ekplorasi dan eksperimen) dan mengajar materi geometri, aljabar, dan kalkulus dan dapat digunakan juga untuk, alat bantu membuat bahan ajar matematika serta meyelesaikan soal matematika.

Novitasari, D., Indrawati, Risfianty, D.K. (2018: 187) mengatakan bahwa "geogebra membantu guru dalam proses 
belajar mengajar matematika dan merupakan software matematika dinamis untuk geometri, aljabar, dan kalkulus. Selain menjadi alat untuk memahami konsep, Geogebra juga digunakan untuk menjelaskan prosedur."

Menurut penelitian yang dilakukan oleh Oktaria, Alam \&Sulistiawati (2016) bahwa penggunaan software geogebra dalam pembelajaran matematika pada materi SPLDV dapat meningkatkan kemampuan representasi matematis. Jika dicari hubungan dengan penelitian tersebut, pada penelitian ini juga diperoleh bahwa mahasiswa mampu merepresentasikan bentuk persamaan kedalam bentuk grafik atau garis dengan lebih cepat dan mudah.

Sama seperti beberapa penelitian yang relevan tersebut, dari penelitian ini didapat bahwa aplikasi komputer yang bernama geogebra sangat membantu untuk menggambarkan titik, garis, kurva dan berbagai bentuk geometri lainnya yang bisa divisualisasikan.

\section{SIMPULAN (PENUTUP)}

Belajar secara mandiri oleh peserta didik bisa terjadi dengan bantuan softwareGeogebra dan mampu membuat siswa lebih aktif dalam pembelajaran, serta peserta didik juga bisa menemukan sendiri solusi permasalahan dengan bantuan software geogebra.

Dalam Penelitian ini, terdapat beberapa kesimpulan dari hasil penelitian yaitu:

1. Software geogebra dapat dengan mudah dimiliki oleh mahasiswa
2. Software geogebra mudah dipelajari oleh mahasiswa

3. Pembelajaran dengan menggunakan software geogebra menyenangkan dan menarik

4. Mahasiswa menjadi termotivasi untuk belajar

5. Soal dapat dengan mudah dan cepat diselesaikan, serta dapat menggambar grafik dengan lebih cepat, menarik dan bervariasi.

\section{UCAPAN TERIMAKASIH}

Pada penelitian ini, banyak kontribusi dari berbagai pihak sehingga penelitian ini bisa selesai. Peneliti mengucapkan terimakasih kepada Pimpinan Fakultas FPMIPA IKIP Gunungsitoli yang telah memberikan izin untuk melakukan penelitian di lingkungan FPMIPA. Serta peneliti juga berterimakasih kepada mahasiswa FPMIPA IKIP Gunungsitoli yang telah turut serta berperan dalam penelitian ini.

\section{DAFTAR PUSTAKA}

Ardina, Fimmatur Rizka. 2016. Lembar Kerja Siswa Berbantuan Geogebra Sebagai Upaya Membantu Pemahaman Siswa Materi Limit Fungsi Aljabar. Jurnal Math Educator Nusantara, 2(1).

Ekawati, Aminah. 2016. Penggunaan Software Geogebradan Microsoft Mathematicdalam Pembelaran Matematika.Math Didactic: Jurnal Pendidikan Matematika,2(3).

Hendriana, Benny. 2017. Aplikasi Komputer "Mengenal Software Komputer" . Jakarta. 
Hosnan, 2013. Pendekatan Saintifik dan Kontekstual dalam Pembelajaran Abad 21. Bogor: Graha Indonesia

Nopiyani D., Turmudi, \& Prabawanto S. 2016. Penerapan Pembelajaran Matematika Realistik Berbantuan GeoGebra untuk Meningkatkan Kemampuan Komunikasi Matematis Siswa SMP. Mosharafa, 5 (2): 45-52.

Novitasari,D.,Indrawati,\&Risfianty,D.K. 2018. Pengembangan Perangkat Pembelajaran Matematika Dengan Pendekatan Saintifik Berbasis GeoGebra Untuk SMA di Mataram. Jurnal Math Educator Nusantara,4(2): 186-197

Oktaria, Alam \& Sulistiawati. 2016. Penggunaan Media Software GeoGebra untuk Meningkatkan Kemampuan Representasi Matematis Siswa SMP Kelas VIII. Kreano, 7(1).

Sagala, Syaiful. 2011. Konsep dan Makna Pembelajaran. Bandung : Alfabeta.

Suparman, M. Atwi. 2014. Desain Instruksional Modren. Panduan Para Pengajar dan Inovator Pendidikan. Jakarta: Erlangga.

Uno, H.B. 2011. Model Pembelajaran. Jakarta: Bumi Aksara

Zayyadi, Lanya, \&Irawati. 2019. Geogebra dan Maple sebagai Media Pembelajaran Matematika untuk Meningkatkan Kualitas Guru Matematika. Abdimas Dewantara, 2(1): 53-61. 